\title{
DETERMINAN PEMBIAYAAN PADA BANK PEMBIAYAAN RAKYAT SYARIAH DI INDONESIA
}

\author{
Uus Ahmad Husaeni \\ Universitas Suryakancana \\ uusahmad1@gmail.com
}

\begin{abstract}
Islamic Rural Bank serves as a financial intermediary to carry out the activities of collecting and distributing funds from the public. Therefore, it is necessary to test whether internal factors, which include deposit funds, capital adequacy ratio, financing to deposit ratio and non-performing financing significantly affects to financing. The purpose of this study is to examine the factors that affect the financing in Islamic rural bank in Indonesia. The analytical tool used in this research is multiple linear regression analysis. The results of the study, to simultaneously show that the Third Party Funds, Capital Adequacy Ratio, Financing to Deposit Ratio and Non Performing Financing significantly affects to Distribution of Funding in SRB (BPRS), while the rest is explained by other factors not enrolled in this study.
\end{abstract}

Keywords: financing, internal factors; Islamic rural banks, multiple regression.

\begin{abstract}
Abstrak
Bank Pembiayaan Rakyat Syariah (BPRS) berfungsi sebagai lembaga intermediasi keuangan dengan melaksanakan kegiatan menghimpun dan menyalurkan dana dari masyarakat. Oleh karena itu, perlu dilakukan pengujian apakah faktor-faktor internal yang meliputi dana pihak ketiga (DPK), rasio kecukupan modal (CAR), rasio FDR (Financing to Deposit Ratio) dan tingkat pembiayaan bermasalah (non performing financing) mempengaruhi penyaluran pembiayaan di BPRS. Penelitian ini bertujuan untuk menguji pengaruh dana pihak ketiga (DPK), rasio kecukupan modal (CAR), rasio FDR (Financing to Deposit Ratio) dan tingkat pembiayaan bermasalah (non performing financing) terhadap penyaluran pembiayaan BPRS. Alat analisis yang digunakan dalam penelitian ini adalah analisis regresi linear berganda. Hasil penelitian, secara simultan menunjukkan bahwa DPK (Dana Pihak Ketiga), CAR (Capital Adequacy Ratio), FDR (Financing to Deposit Ratio) dan NPF (Non Performing Financing) berpengaruh signifikan terhadap penyaluran pembiayaan BPRS, sedangkan sisanya dijelaskan oleh faktor lain yang tidak diikutsertakan dalam penelitian ini.
\end{abstract}

Kata Kunci: pembiayaan, faktor internal, bank pembiayaan rakyat syariah, regresi berganda

Diterima: 23 Januari 2017; Direvisi: 2 Februari 2017; Disetujui: 17 Februari 2017 


\section{PENDAHULUAN}

Sistem ekonomi syariah atau biasa disebut dengan Ekonomi Islam, semakin populer bukan hanya di negara-negara Islam tapi juga di negara-negara barat. Banyak kalangan melihat, Islam dengan sistem nilai dan tatanan normatifnya sebagai faktor penghambat pembangunan. Penganut paham liberalisme dan pragmatisme sempit menilai bahwa kegiatan ekonomi dan keuangan akan semakin meningkat dan berkembang bila dibebaskan dari nilai-nilai normatif dan ramburambu ilahi (Akhtar, 2011).

Keberadaan Perbankan Syariah sebagai bagian dari sistem Ekonomi Islam diharapkan dapat mendorong perkembangan perekonomian suatu negara. Tujuan dan fungsi Perbankan Syariah dalam perekonomian adalah kemakmuran ekonomi yang meluas, tingkat kerja penuh dan tingkat pertumbuhan ekonomi yang optimum, keadilan sosial-ekonomi dan distribusi pendapatan serta kekayaan yang merata, stabilitas nilai uang, mobilisasi dan investasi tabungan yang menjamin adanya pengembalian yang adil dan pelayanan yang efektif. Bank Syariah didirikan dengan tujuan untuk mempromosikan dan mengembangkan penerapan prinsip-prinsip Islam, syariah dan tradisinya ke dalam transaksi keuangan dan perbankan serta bisnis lain yang terkait.

Menurut Undang-Undang Perbankan No. 10 Tahun 1998, jenis Perbankan terdiri dari Bank Umum dan Bank Perkreditan Rakyat (BPR). Sedangkan pada Perbankan Syariah, BPR yang dimaksud yaitu Bank Pembiayaan Rakyat Syariah (BPRS). Perbankan Syariah di Indonesia terdiri dari Bank Umum Syariah (BUS), Unit Usaha Syariah (UUS), dan Bank Pembiayaan Rakyat Syariah (BPRS). Pada umumnya BUS, UUS, dan BPRS merupakan bank alternatif yang diperuntukkan bagi masyarakat yang menjalankan usaha mikro kecil menengah dan yang menginginkan perbankan yang benar-benar syariah (menjalankan prinsip-prinsip syariah). Kehadiran Bank Pembiayaan Rakyat Syariah (BPRS) di Indonesia semakin menambah daftar nama perbankan syariah, karena Bank Pembiayaan Rakyat Syariah (BPRS) dalam sistem perbankan di Indonesia merupakan sebuah lembaga keuangan dalam memenuhi kebutuhan masyarakat atas transaksi pembiayaan yang tidak berbasis riba. Sampai dengan juni 2016, jumlah BPRS di Indonesia mencapai 
165 dengan jumlah kantor 428 dan jumlah pekerja mencapai 4.495 orang (Husaeni, dkk, 2016).

Penyaluran pembiayaan merupakan aktivitas utama BPRS sehingga pendapatan margin bagi hasil menjadi pendapatan utama BPRS, namun pembiayaan juga merupakan sumber resiko bagi BPRS yang tercermin dari pembiayaan non lancar (non performing financing). Kemampuan menyalurkan pembiayaan oleh Perbankan dipengaruhi berbagai faktor yang dapat ditinjau dari sisi internal dan eksternal. Dari sisi internal bank terutama dipengaruhi oleh kemampuan bank dalam menghimpun dana masyarakat dan penetapan margin pembiayaan serta memperhatikan rasio-rasio keuangan.

\section{Gambar 1. Penyaluran Pembiayaan di BPRS Tahun 2014-2016}

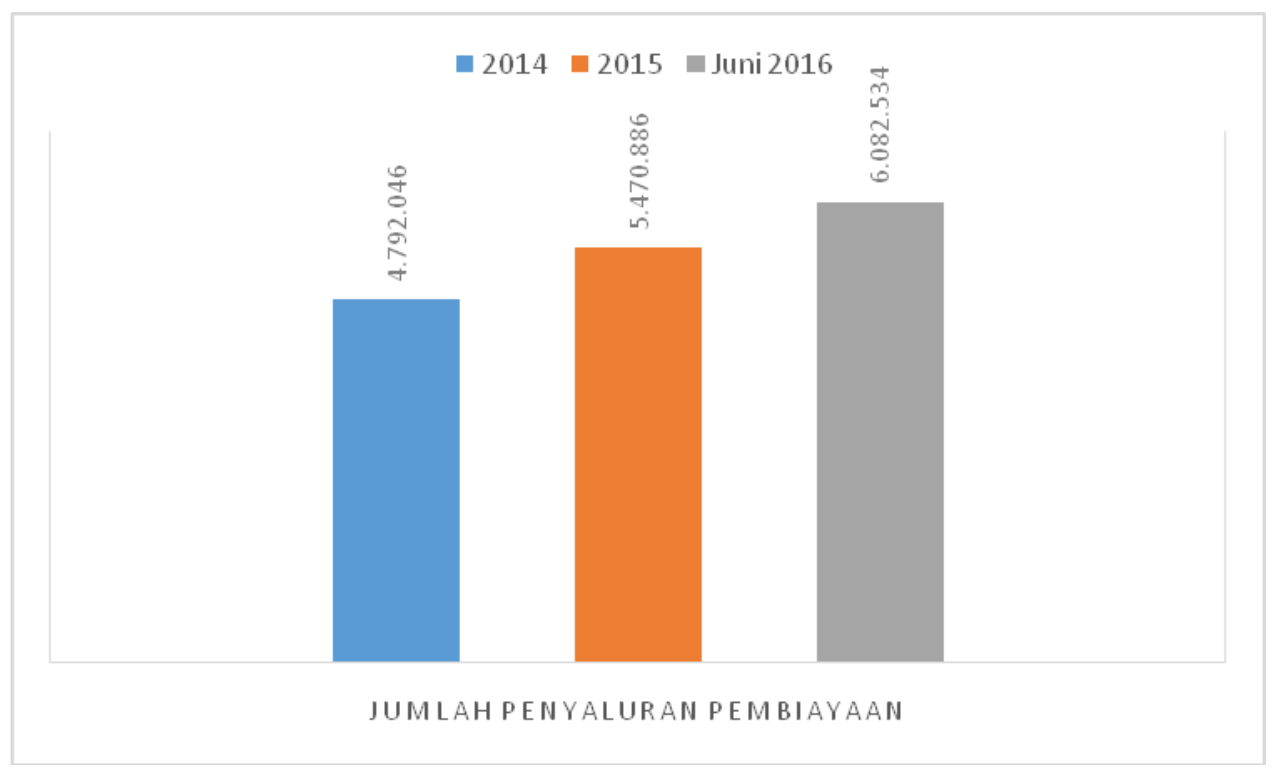

Sumber: Otoritas Jasa Keuangan (diolah)

Dari Gambar 1, dapat diperlihatkan bahwa penyaluran pembiayaan BPRS setiap tahun mengalami kenaikan yang cukup signifikan. Pada tahun 2014, jumlah penyaluran pembiayaan mencapai $\mathrm{Rp}$ 4,792 Triliun dan pada tahun 2015 total penyaluran pembiayaan pada BPRS mencapai Rp 5,470 Triliun. Sedangkan pada bulan Juni 2016, jumlah total penyaluran pembiayaan mencapai Rp 6,082 Triliun.

Penelitian ini akan meneliti faktor-faktor yang mempengaruhi pembiayaan dari sisi internal bank yaitu Dana Pihak Ketiga (DPK), Capital Adequacy Ratio (CAR), 
Financing to Deposit Ratio (FDR) dan Non Performing Financing (NPF) terhadap Penyaluran Pembiayaan pada BPRS di Indonesia pada periode Januari 2014-Juni 2016. Dimana variabel-variabel tersebut merupakan rasio yang dapat digunakan sebagai tolak ukur kesehatan suatu bank.

\section{METODE}

Teknik analisis yang dipergunakan dalam penelitian ini ialah teknik regresi berganda. Namun sebelum dilakukan pengujian regresi berganda perlu dilakukan pengujian asumsi klasik, untuk memastikan apakah model regresi linier berganda yang digunakan tidak terdapat masalah normalitas, multikolonieritas, heterokedastisitas dan autokorelasi. Setelah dilakukan uji asumsi klasik, maka selanjutnya ialah uji hipotesis yang meliputi uji t, uji $\mathrm{F}$, dan koefisien determinasi. Persamaan matematis yang dipergunakan dalam penelitian ini ialah

Pembiayaan $_{t}=\alpha+\beta_{1} D P K_{t}+\beta_{2} C A R_{t}+\beta_{3} F D R_{t}+\beta_{4} N P F_{t}$

Keterangan: Pembiayaan ialah jumlah penyaluran Pembiayaan pada BPRS di Indonesia periode t; DPK ialah pada BPRS di Indonesia periode t; CAR ialah rasio kecukupan modal pada BPRS di Indonesia periode t; FDR ialah rasio pembiayaan terhadap dana pihak ketiga pada BPRS di Indonesia periode t; NPF ialah rasio pembiayaan bermasalah pada BPRS di Indonesia periode $t$.

\section{HASIL DAN PEMBAHASAN}

Hasil

Berdasarkan pengolahan data diperoleh nilai maksimum, minimum, ratarata (mean) dan standar deviasi (standard deviation) dari masing-masing variabel penelitian terlihat pada Tabel 1 . Berdasarkan Tabel 1 dapat dilihat bahwa $\mathrm{N}=30$ waktu amatan, variabel independen Dana Pihak Ketiga (DPK) mempunyai nilai minimum 3,37 Triliyun Rupiah, nilai maksimum 5,05 Triliyun Rupiah, nilai standar deviasi (standard deviation) sebesar 503 Miliyar Rupiah dan nilai rata-rata (mean) sebesar 4,1 Triliyun Rupiah. Nilai rata-rata (mean) yang lebih besar dibandingkan nilai standar deviasi (standard deviation) menunjukkan bahwa data terdistribusi dengan baik. Variabel independen Capital Adequacy Ratio (CAR) mempunyai nilai minimum 20,22\%, nilai maksimum 24,67\%, nilai standar deviasi (standard 
deviation) sebesar $1,16 \%$ dan nilai rata - rata (mean) sebesar 22,27\%. Nilai rata rata (mean) yang lebih besar dibandingkan nilai standar deviasi (standard deviation) menunjukkan bahwa data terdistribusi dengan baik.

Tabel 1. Statistik Deskriptif

\begin{tabular}{lrrrrrr}
\hline & DPK & \multicolumn{1}{c}{ CAR } & FDR & NPF & PenyL_Pemb \\
\hline N $\quad$ Valid & 30 & 30 & 30 & 30 & 30 \\
Mean & 0 & 0 & 0 & 0 & 0 \\
Median & 4195116,40 & 22,2737 & 126,8013 & 8,9773 & 5321680,07 \\
Mode & 4126018,00 & 22,1800 & 126,6250 & 9,0950 & 5271079,50 \\
Std. Deviation & $3374325^{\mathrm{a}}$ & 21,73 & 121,55 & $7,71^{\mathrm{a}}$ & $442267 \mathrm{a}^{\mathrm{a}}$ \\
Variance & 503118,305 & 1,16562 & 4,73763 &, 73898 & 543695,416 \\
Range & 253128028437, & 1,359 & 22,445 &, 546 & 295604705648,9 \\
Minimum & 7 & & & & 6 \\
Maximum & 1684962 & 4,45 & 17,12 & 2,65 & 2041160 \\
Sum & 3374325 & 20,22 & 118,56 & 7,71 & 4422674 \\
\hline
\end{tabular}

Variabel independen Financing to Deposit Ratio (FDR) mempunyai nilai minimum 118,56\%, nilai maksimum 135,68\%, nilai standar deviasi (standard deviation) sebesar 4,73\% dan nilai rata-rata (mean) sebesar 126,8\%. Nilai rata - rata (mean) yang lebih besar dibandingkan nilai standar deviasi (standard deviation) menunjukkan bahwa data terdistribusi dengan baik. Variabel independen Non Performing Financing (NPF) mempunyai nilai minimum 7,71\%, nilai maksimum 10,36\%, nilai standar deviasi (standard deviation) sebesar 0,73\% dan nilai rata-rata (mean) sebesar 8,97\%. Nilai rata-rata (mean) yang lebih besar dibandingkan nilai standar deviasi (standard deviation) menunjukkan bahwa data terdistribusi dengan baik. Variabel dependen Pembiayaan mempunyai nilai minimum 4,42 Triliyun Rupiah, nilai maksimum 6,46 Triliyun Rupiah, nilai standar deviasi (standard deviation) sebesar 543 Milyar Rupiah dan nilai rata-rata (mean) sebesar 5,32 Triliyun Rupiah. Nilai rata-rata (mean) yang lebih besar dibandingkan nilai standar deviasi (standard deviation) menunjukkan bahwa data terdistribusi dengan baik.

Berdasarkan Uji-F diperoleh hasil bahwa nilai F-hitung sebesar 303,116 dengan tingkat signifikansi sebesar 0,000. Karena tingkat signifikansi lebih kecil dari 0,05 , dan nilai F-hitung $(303,116)>$ F-tabel $(2,76)$ maka model regresi dapat digunakan untuk memprediksi variabel dependen Pembiayaan atau secara 
bersama-sama variabel independen DPK, CAR, FDR, dan NPF berpengaruh terhadap variabel dependen Penyaluran Pembiayaan.

Tabel 2 Hasil Uji F

ANOVA $^{\mathrm{a}}$

\begin{tabular}{rrrrrrr}
\hline Model & & Sum of Squares & Df & Mean Square & F & Sig. \\
\hline & Regression & 8399348635357, & 4 & 2099837158839, & 303,116 &, $000^{\mathrm{b}}$ \\
1 & Residual & 173187828462,7 & 25 & 6927513138,5 & & \\
& Total & 8572536463819, & 29 & & & \\
& 9 & 9 & & & & \\
\hline
\end{tabular}

a. Dependent Variable: PenyL_Pemb

b. Predictors: (Constant), NPF, FDR, CAR, DPK

Berdasarkan Tabel 3 diperoleh hasil bahwa nilai adjusted R2 sebesar 0,977, hal ini berarti 97,7\% variasi penyaluran pembiayaan dapat dijelaskan oleh variasi dari keempat variabel independen DPK, CAR, FDR, dan NPF. Sedangkan sisanya sebesar 2,3\% dijelaskan oleh sebab-sebab lain di luar model.

Tabel 3. Koefisien Determinasi Model Summaryb

\begin{tabular}{lrrrrrr}
\hline Model & $\mathrm{R}$ & R Square & $\begin{array}{c}\text { Adjusted R } \\
\text { Square }\end{array}$ & \multicolumn{2}{c}{$\begin{array}{c}\text { Std. Error of } \\
\text { the Estimate }\end{array}$} & \multicolumn{2}{c}{ Change Statistics } \\
R Square & F Change \\
& & & & Change & \\
\hline 1 &, $990^{\mathrm{a}}$ &, 980 &, 977 & 83231,684 &, 980 & 303,116 \\
\hline
\end{tabular}

a. Predictors: (Constant), NPF, FDR, CAR, DPK

b. Dependent Variable: PenyL_Pemb.

Berdasarkan persamaan regresi linier berganda pada Tabel 4 diperoleh koefisien regresi DPK sebesar (+) 1,081. Koefisien tersebut mengindikasikan adanya hubungan positif antara variabel DPK terhadap penyaluran pembiayaan. Koefisien regresi CAR sebesar (-) 41678,220. Koefisien tersebut mengindikasikan adanya hubungan negatif antara variabel CAR terhadap penyaluran pembiayaan. Koefisien regresi FDR sebesar (+) 28202,524. Koefisien tersebut mengindikasikan adanya hubungan positif antara variabel FDR terhadap penyaluran pembiayaan. Sedangkan koefisien regresi NPF sebesar (+) 22942,973. Koefisien tersebut mengindikasikan adanya hubungan positif antara variabel NPF terhadap penyaluran pembiayaan. 
Berdasarkan koefisien beta regresi pada tabel 5 dapat disimpulkan bahwa variabel CAR memiliki pengaruh yang paling besar terhadap pembiayaan dengan nilai koefisien beta regresi sebesar (-) 41678,220, diikuti variabel FDR, NPF dan DPK dengan nilai beta regresi berturut - turut sebesar (+) 28202,524, (+) 22942,973 dan (+) 1,081.

\begin{tabular}{rrrrrr}
\multicolumn{7}{c}{ Tabel 4. Hasil Uji-t } \\
Coefficients
\end{tabular}

a. Dependent Variable: PenyL_Pemb

Dana Pihak Ketiga (DPK) berpengaruh positif dan signifikan terhadap penyaluran pembiayaan pada BPRS, hasil analisis regresi berganda menunjukkan bahwa DPK memiliki nilai t-hitung $(15,306)>t$ tabel $(1.708)(\mathrm{df}=25, \operatorname{Pr}=0,05)$ yang berarti $\mathrm{H}_{1}$ diterima. Hal ini juga didukung oleh nilai probability value dari DPK $(0,000)<0,005$. Capital Adequacy Ratio (CAR) berpengaruh positif dan signifikan terhadap penyaluran pembiayaan pada BPRS, hasil analisis regresi berganda menunjukkan bahwa CAR memiliki nilai t-hitung $(-1,765)<\mathrm{t}$-tabel $(1,708)(\mathrm{df}=25$, $\operatorname{Pr}=0,05$ ) yang berarti $\mathrm{H}_{2}$ ditolak. Hal ini juga didukung oleh nilai probability value dari CAR $(0,090)>0,005$.

Financing to Deposit Ratio (FDR) berpengaruh positif dan signifikan terhadap penyaluran pembiayaan pada BPRS, hasil analisis regresi berganda menunjukkan bahwa FDR memiliki nilai t-hitung $(4,180)>\mathrm{t}$-tabel $(1,708)(\mathrm{df}=25$, Pr $=0,05$ ) yang berarti $\mathrm{H}_{3}$ diterima. Hal ini juga didukung oleh nilai probability value dari FDR $(0,000)<0,005$. Non Performing Financing (NPF) berpengaruh negatif dan signifikan terhadap penyaluran pembiayaan pada BPRS, hasil analisis regresi berganda menunjukkan bahwa NPF memiliki nilai t-hitung $(0,737)<t$ tabel $(1,708)$ $(\mathrm{df}=18, \operatorname{Pr}=0,05)$ yang berarti $\mathrm{H}_{4}$ ditolak. Hal ini juga didukung oleh nilai probability value dari $\operatorname{FDR}(0,468)>0,005$. 


\section{Pembahasan}

Hasil penelitian ini mengindikasikan bahwa peningkatan atau penurunan dana pihak ketiga (DPK) selama periode penelitian berpengaruh positif dan signifikan terhadap penyaluran pembiayaan. Koefisien variabel Dana Pihak Ketiga (DPK) bernilai positif, sehingga perkembangan dana pihak ketiga (DPK) berbanding lurus dengan perkembangan pembiayaan. Hasil penelitian ini serupa dengan yang dilakukan oleh Ali dan Miftahurrohman (2016); Jamilah (2016); Wahyudi (2016).

Penyaluran pembiayaan menjadi prioritas utama bank dalam pengalokasian dananya. Hal ini dikarenakan sumber dana bank berasal dari masyarakat sehingga bank harus menyalurkan kembali dana pihak ketiga (DPK) yang berhasil dihimpun kepada masyarakat dalam bentuk pembiayaan. Hal ini sejalan dengan fungsi bank sebagai perantara keuangan (financial intermediary). Dari hasil penelitian di atas dapat menjelaskan bahwa BPRS mampu menjalankan fungsi intermediasinya dengan baik, karena penyaluran pembiayaan tumbuh seiring dengan pertumbuhan dari dana pihak ketiga (DPK).

Peningkatan pembiayaan dan penghimpunan dana masyarakat selalu diupayakan untuk menjaga aktifitas operasional dan keuangan di perbankan syariah. Dalam melaksanakan aktivitas pembiayaan dan pemenuhan kebutuhan pada anggota, dipengaruhi oleh besar kecilnya Dana Pihak Ketiga (DPK) yang berhasil dihimpun sebagai penggerak aktivitas bisnis perbankan syariah. Dana pihak ketiga atau simpanan bank, dapat diperoleh dalam bentuk giro, tabungan, deposito atau bentuk lainnya yang dipersamakan dengan itu. Pertumbuhan Dana Pihak Ketiga (DPK) akan mengakibatkan pertumbuhan penyaluran kredit yang pada akhirnya rasio tingkat likuiditas Financing to Deposit Ratio (FDR) juga akan meningkat (Pratama, 2010).

Hasil penelitian mengindikasikan bahwa peningkatan atau penurunan rasio kecukupan modal (CAR) selama periode penelitian tidak berpengaruh terhadap penyaluran pembiayaan. Koefisien variabel rasio kecukupan modal (CAR) bernilai negatif, sehingga perkembangan rasio kecukupan modal (CAR) berbanding terbalik dengan perkembangan pembiayaan. Hasil analisis menunjukkan bahwa rasio kecukupan modal (CAR) tidak berpengaruh. Hal ini, dikarenakan BPRS 
memiliki sumber permodalan yang kuat dari para pemegang sahamnya dan pihak manajemen BPRS mampu mengelola resiko yang timbul dari aktiva-aktivanya (penempatan pada bank lain, pembiayaan yang disalurkan, aktiva tetap dan inventaris serta rupa-rupa aktiva). Hasil penelitian ini berbeda dengan yang didapat oleh Ali dan Miftahurrohman (2016).

Capital Adequacy Ratio (CAR) merupakan rasio kinerja keuangan bank sebagai indikator terhadap kemampuan bank untuk menutupi penurunan aktivanya sebagai akibat dari kerugian-kerugian bank yang disebabkan oleh aktiva berisiko. Bila tingkat kecukupan modal atau CAR bank baik, maka masyarakat akan tertarik untuk melakukan penyimpanan dan pengambilan pembiayaan atau kredit di bank. Arditya (2011) menjelaskan bahwa semakin tinggi nilai CAR mengindikasikan bahwa bank telah mempunyai modal yang cukup baik dalam menunjang kebutuhannya serta menanggung risiko-risiko yang ditimbulkan termasuk di dalamnya risiko kredit.

Gambar 2. Pertumbuhan Rasio Kecukupan Modal BPRS

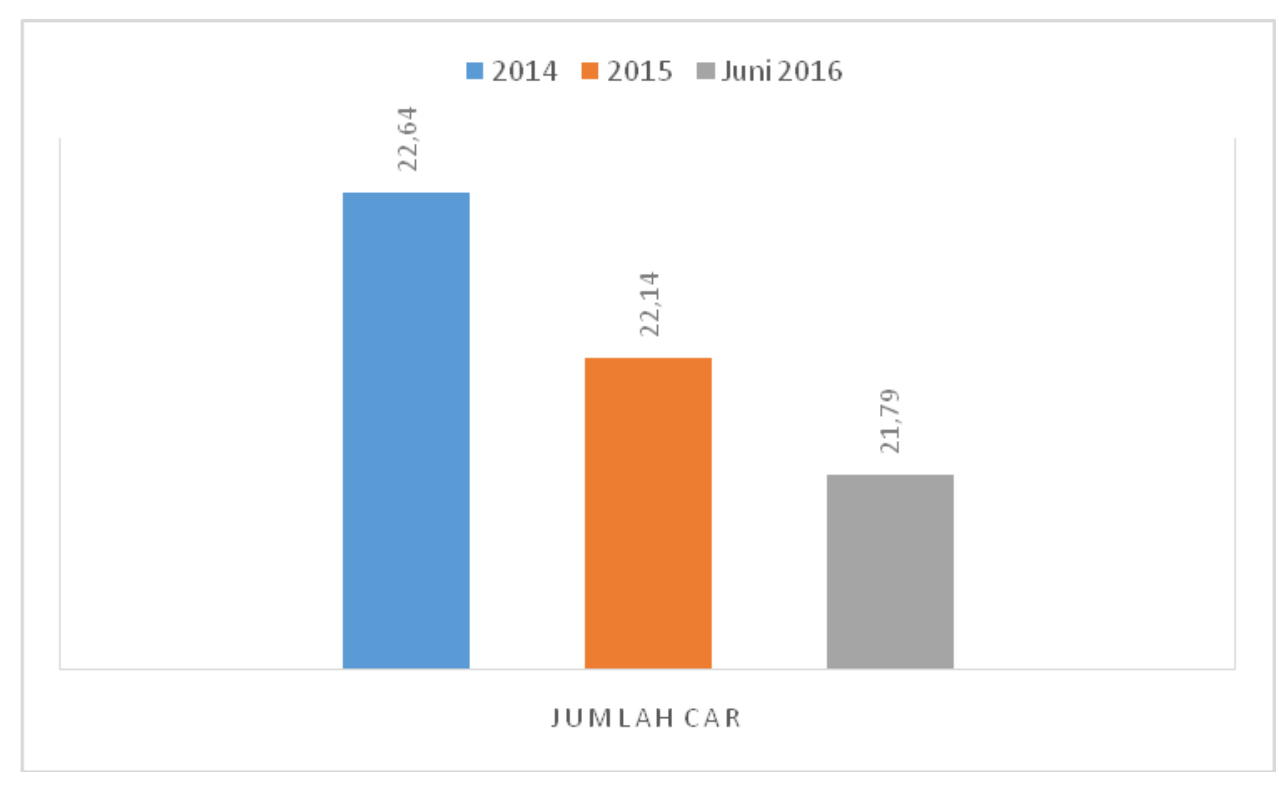

Sumber: Otoritas Jasa Keuangan (diolah)

Gambar 2 menunjukkan bahwa pertumbuhan CAR BPRS setiap tahun mengalami penurunan. Pada tahun 2014, jumlah CAR mencapai $22.64 \%$ dan pada tahun 2015 total CAR pada BPRS mencapai 22.14\%. Sedangkan pada bulan Juni 
2016, jumlah total CAR mencapai 21.79\%. Hal ini, menandakan bahwa semakin rendah nilai CAR mengindikasikan bahwa bank belum maksimal dalam mengelola modal dan belum maksimal dalam menanggung risiko-risiko yang ditimbulkan termasuk didalamnya risiko kredit.

Hasil penelitian ini, mengindikasikan bahwa peningkatan atau penurunan Financing to Deposit Ratio (FDR) selama periode penelitian berpengaruh positif dan signifikan terhadap penyaluran pembiayaan. Koefisien variabel Financing to Deposit Ratio (FDR) bernilai positif, sehingga perkembangan Financing to Deposit Ratio (FDR) berbanding lurus dengan perkembangan pembiayaan. Pada prinsipnya, semakin tinggi Financing to Deposit Ratio (FDR) menunjukkan semakin riskan kondisi likuiditas bank, sehingga Financing to Deposit Ratio (FDR) yang semakin tinggi akan dapat menurunkan penyaluran pembiayaan. Akan tetapi yang terjadi pada BPRS berbeda, semakin tinggi Financing to Deposit Ratio (FDR) tidak menyurutkan BPRS untuk terus meningkatkan outstanding pembiayaannya. Hal ini, dikarenakan diimbangi oleh perkembangan Dana Pihak Ketiga (DPK) yang juga tumbuh secara signifikan, sehingga BPRS tidak khawatir dengan kondisi likuiditasnya dan terus meningkatkan penyaluran pembiayaannya selama periode penelitian. Hal ini, menunjukkan bahwa BPRS mampu mengelola Dana Pihak Ketiga (DPK) secara optimal untuk disalurkan dalam bentuk pembiayaan kepada masyarakat.

Financing to Deposit Ratio (FDR) menggambarkan kemampuan bank membayar kembali penarikan yang dilakukan nasabah deposan dengan mengandalkan pembiayaan yang diberikan sebagai sumber likuiditasnya. Semakin tinggi rasio ini, semakin rendah kemampuan likuiditas bank. Hal ini dikarenakan penyaluran pembiayaan merupakan salah satu tujuan dari penghimpunan dana bank, yang sekaligus memberikan kontribusi pendapatan terbesar bagi bank. Semakin banyak pembiayaan yang disalurkan, maka semakin illiquid suatu bank, karena seluruh dana yang berhasil dihimpun telah disalurkan dalam bentuk pembiayaan, sehingga tidak terdapat kelebihan dana untuk dipinjamkan lagi atau untuk diinvestasikan (Amriani, 2012). 
Hasil penelitian, mengindikasikan bahwa peningkatan atau penurunan Non Performing Financing (NPF) selama periode penelitian berpengaruh negatif dan tidak signifikan terhadap penyaluran pembiayaan. Koefisien variabel Non Performing Financing (NPF) bernilai negatif, sehingga perkembangan NPF berbanding terbalik dengan perkembangan penyaluran pembiayaan. Hasil analisis menunjukkan bahwa Non Performing Financing (NPF) berpengaruh negatif dan tidak signifikan terhadap perkembangan penyaluran pembiayaan BPRS. Hal ini, dikarenakan BPRS memiliki Non Performing Financing (NPF) yang relatif kecil, masih berada dibawah batas toleransi ketentuan dari Bank Indonesia, sehingga naik turunnya Non Performing Financing (NPF) di BPRS berpengaruh tidak signifikan terhadap penyaluran pembiayaan yang terus berkembang selama periode penelitian. Hal ini, menunjukkan bahwa BPRS memiliki kemampuan manajemen yang baik dalam mengelola portofolio pembiayaan, sehingga dapat meminimalisir terjadinya pembiayaan bermasalah.

Sebagai indikator yang menunjukkan kerugian akibat risiko kredit adalah tercermin dari besarnya Non Performing Loan (NPL), dalam terminologi bank syariah disebut Non Performing Financing (NPF). Non Performing Financing (NPF) adalah rasio antara pembiayaan yang bermasalah dengan total pembiayaan yang disalurkan oleh bank syariah. Berdasarkan kriteria yang sudah ditetapkan oleh Bank Indonesia kategori yang termasuk dalam NPF adalah pembiayaan kurang lancar, diragukan dan macet.

Non performing financing (NPF) akan berdampak pada menurunnya tingkat bagi hasil yang dibagikan pada pemilik dana. Hubungan antara bank dan nasabah didasarkan pada dua unsur yang saling terkait, yaitu hukum dan kepercayaan. Suatu bank hanya dapat melakukan kegiatan dan mengembangkan usahanya apabila nasabah percaya untuk menempatkan uangnya. Kemudian setelah menghimpun dana dari masyarakat dalam bentuk simpanan, bank kemudian menyalurkan kembali kepada masyarakat dalam rangka meningkatkan taraf hidup masyarakat (Muntoha 2011).

Gambar 3 memperlihatkan bahwa pertumbuhan NPF setiap tahun mengalami kenaikan. Hal ini, menunjukan bahwa tingkat pembayaran pembiayaan 
nasabah tidak lancar (kredit macet) setiap tahun mengalami kenaikan. Pada tahun 2014, NPF BPRS mencapai 7.89 persen dan pada tahun 2015 NPF berada di posisi tertinggi sebesar 9.55 persen dan merupakan batas berbahaya dari sebuah lembaga keuangan jika NPF atau NPL mereka diatas batas maksimum yaitu 10 persen. Sehingga, jika tidak bisa dikendalikan dalam jangka panjang bisa menimbulkan kebangkrutan. Sedangkan, pada Juni 2016 NPF BPRS turun 0.18 persen menjadi 9.37 persen.

\section{Gambar 3. Perkembangan Rasio NPF di BPRS}

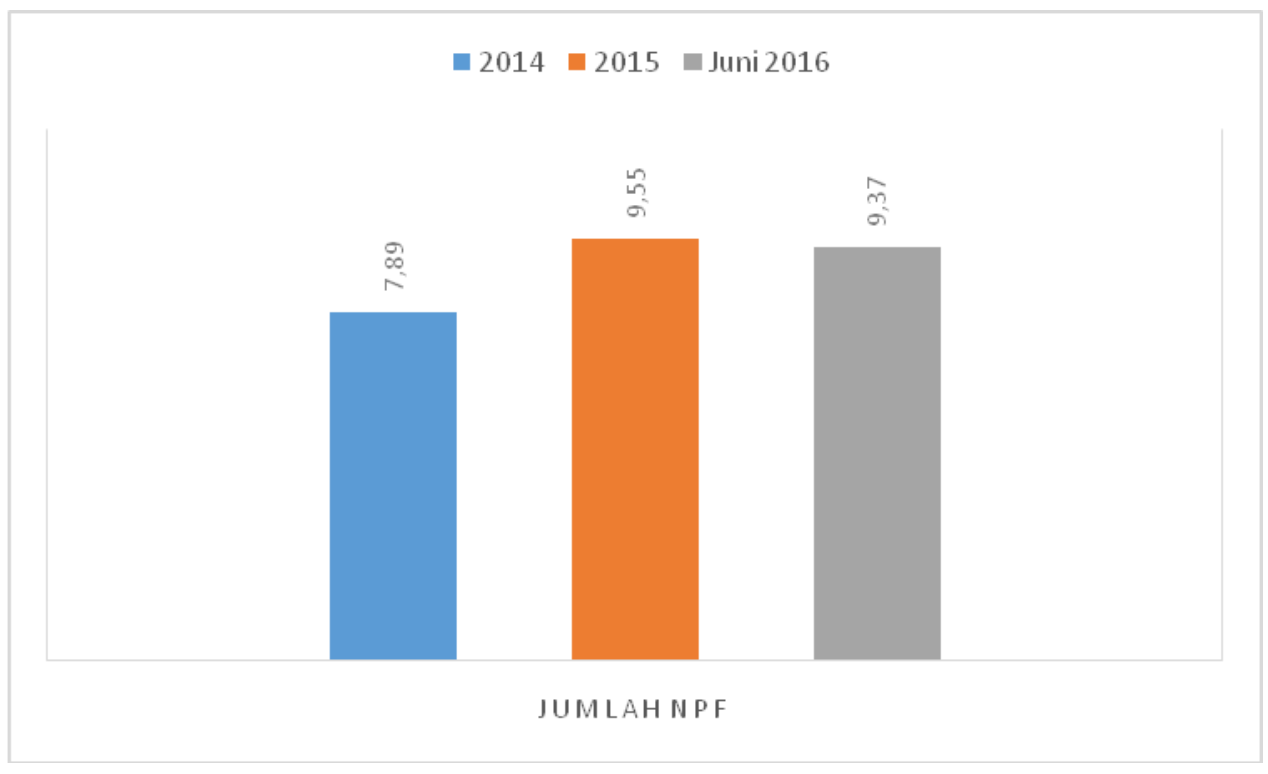

Sumber: Otoritas Jasa Keuangan (diolah).

Qolby (2013) dengan menggunakan model koreksi kesalahan (ECM) menemukan bahwa dalam jangka pendek hanya dana pihak ketiga yang mempengaruhi jumlah penyaluran pembiayaan. Sedangkan dalam jangka panjang dana pihak ketiga, sertifikat wadiah Bank Indonesia, dan tingkat profitabilitas (ROA) berpengaruh positif terhadap jumlah penyaluran pembiayaan pada bank syariah di Indonesia.

\section{SIMPULAN}

Hasil empiris menunjukkan bahwa hanya variabel dana pihak ketiga dan rasio FDR yang berpengaruh terhadap jumlah penyaluran pembiayaan pada bank pembiayaan rakyat syariah di Indonesia. Sedangkan variabel rasio kecukupan 
modal dan tingkat pembiayaan bermasalah tidak berpengaruh terhadap jumlah penyaluran pembiayaan di bank pembiayaan rakyat syariah. Kemudian, apabila dilakukan pengujian secara simultan menunjukkan bahwa seluruh variabel bebas berpengaruh terhadap jumlah penyaluran pembiayaan pada bank pembiayaan rakyat syariah. Hasil ini berimplikasi bahwa bank pembiayaan rakyat syariah harus mampu meningkatkan jumlah dana pihak ketiga apabila hendak menaikkan jumlah penyaluran pembiayaan. Namun hal yang harus diingat, pembiayaan yang semakin tinggi akan rawan terhadap tingkat pembiayaan bermasalah.

\section{PUSTAKA ACUAN}

Akhtar, et al. (2011). Liquidity Risk Management: A Comparative Study Between Conventional and Islamic Bank of Pakistan. Interdisciplinary Journal of Research in Business, Vol 1 (6): 50-57.

Ali, H. \& Miftahurrohman. (2016). Determinan yang Mempengaruhi Pembiayaan Murabahah Pada Perbankan Syariah di Indonesia. Esensi: Jurnal Bisnis dan Manajemen. Vol 6, No. 1: 31-44.

Amriani. F.R. (2012). Analisis Pengaruh CAR, NPL, BOPO, dan NIM Terhadap LDR pada Bank BUMN Persero di Indonesia Periode 2006-2010. (Skripsi Tidak Diterbitkan). Makasar: Universitas Hasanudin.

Arditya, P. (2011). Pengaruh Capital Adequacy Ratio (CAR), Non Performing Loan (NPL), BOPO, Return on Asset (ROA) dan Net Interest Margin (NIM) terhadap Loan to Deposit Ratio (LDR). (Skripsi Tidak Dipublikasikan). Jakarta: Universitas Gunadarma.

Husaeni, U.A. dkk. (2016). Analysis of the Effect Third Party Funds and Non Performing Financing toward Return on Assets of Sharia Rular Bank (BPRS) in Indonesia in the Year 2014 to June 2016. Procedings. ICEBUSS, International Conference on Economic, Business and Social Sciences.

Jamilah. (2016). Faktor-faktor yang Mempengaruhi Pembiayaan Mudharabah Pada Bank Umum Syariah di Indonesia. Jurnal Ilmu dan Riset Akuntansi. Vol. 5 (4): $1-20$.

Muntoha, I. (2011). Pengaruh Gross Domestic Product, Inflasi, dan Kebijakan Jenis Pembiayaan Terhadap Rasio Non Performing Financing Bank Umum 
Syariah di Indonesia Periode 2005 sampai 2010. (Skripsi Tidak Dipublikasikan). Semarang: Universitas Diponegoro

Pratama, B.A. (2010). Analisis Faktor-Faktor Yang Mempengaruhi Kebijakan Penyaluran Kredit Perbankan (Studi Pada Bank Umum di Indonesia Periode Tahun 2005-2009). (Tesis Tidak Dipublikasikan). Semarang: Universitas Diponegoro.

Qolby, M. L. (2013). Faktor-faktor yang Mempengaruhi Pembiayaan Pada Perbankan Syariah di Indonesia Periode Tahun 2007-2013. Economics Development Analysis Journal Vol 2 (4): 367-383.

Wahyudi, A. (2016). Determinan Pembiayaan Murabahah Pada Unit Usaha Syariah: Model Regresi Panel. Esensi: Jurnal Bisnis dan Manajemen. Vol. 6, No. 2: 227236. 